\title{
Path Analysis and Correlation Study of Yield and Its Measure Contributing Traits in Bottle Gourd (Lagenaria siceraria (Mol.) Standl)
}

\author{
R.L. Raut ${ }^{1,3 *}$, S.P. Mishra ${ }^{2}$ and Sharad Bisen ${ }^{1}$ \\ ${ }^{1}$ Jawaharlal Nehru Krishi Vishwavidyalaya, Jabalpur (M.P.) PIN 482004 \\ ${ }^{2}$ Mahatma Gandhi Gramodaya Chitrakoot Vishwavidyalaya, Chitrakoot, Satna (M.P.), India \\ ${ }^{3}$ Rana Hanuman Singh Krishi Vigyan Kendra, Badgaon, Post - Pala, Block - Kirnapur, \\ Balaghat, Madhya Pradesh, India 481115
}

*Corresponding author

\begin{tabular}{|c|c|}
\hline & A B S T R A C T \\
\hline Keywords & \multirow{4}{*}{$\begin{array}{l}\text { An experiment conducted on bottle gourd to study the path coefficient analysis in } \\
\text { bottle gourd at Zonal Agriculture Research Station, Chhindwara (J.N.K.V.V., } \\
\text { Jabalpur). The experiment was laid out in RCBD and on the basis of pooled } \\
\text { analysis (summer } 2008 \text { and kharif 2008). On the basis of pooled analysis } \\
\text { correlation coefficient of fruit yield per plant was expressed significant and } \\
\text { positive with days to appearance of first male flower, number of male flower per } \\
\text { plant, number of female flower per plant, fruit setting percentage, length of fruit, } \\
\text { weight of fruit and number of fruits per plant. However, association of this trait } \\
\text { was recorded significant and negative with sex ratio and circumference of fruit, } \\
\text { which indicated that effective improvement in yield through these components } \\
\text { could be achieved. }\end{array}$} \\
\hline $\begin{array}{l}\text { Bottle gourd, Path } \\
\text { Coefficient } \\
\text { Analysis, } \\
\text { Correlation } \\
\text { Coefficients, Yield } \\
\text { contributing traits }\end{array}$ & \\
\hline Article Info & \\
\hline $\begin{array}{l}\text { Accepted: } \\
\text { 12 November } 2018 \\
\text { Available Online: } \\
\text { 10 December } 2018\end{array}$ & \\
\hline
\end{tabular}

\section{Introduction}

Bottle gourd [Lagenaria siceraria (Mol.) Standl] is one of the oldest cultivated plants in the world. It has high yield potential and adoptability to diverse climatic condition hold a great promise to cope up with the per caput per day requirement of $285 \mathrm{~g}$ vegetables in balance diet (Singh 1998) of fast growing population pressure and greater dietary awareness, particularly among the literate mosses of a country like India. By and large considered as poor man's vegetable, bottle gourd is now making its head way even among the elite mosses. A rich source of vitamins, iron and minerals it is an excellent diet for people having digestive problems.

The area production and productivity of cucurbits in the world is about 8.5 million ha., 179.09 million tonnes and 20.98 tonnes/ha. respectively. China is leading country in the world producing 113.87 million tonnes of cucurbits from acreage of 4.3 million hectare and the productivity being 26.00 tonnes/ha. Whereas, in India area, production and 
productivity of cucurbits are 0.43 million hectare, 4.52 million tones and 10.52 tonnes/hectare respectively (Rajwade, 2006). Productivity of gourds (bottle gourd, ridge gourd, bitter gourd, snack gourd wax gourd and smooth gourd), pumpkin and squash in the world, China and India is 12.97, 18.70 and $9.72 \mathrm{t} / \mathrm{ha}$ respectively. The total area under various gourd (bottle gourd, ridge gourd, bitter gourd, snack gourd wax gourd etc.) in the country was 0.36 million hectare with an annual production of 3.5 million tonnes (Rajwade, 2006). Statistics of cucurbits shows that India has go a long way from the view point of area, production and productivity and emphasizes to go for improvement in term of breeding programme, production technology, marketing and post harvest management.

As large numbers of factors are involved in correlation studies, their association becomes more complex. Under such circumstances, the path coefficient analysis help in removing the complication by measuring the direct and indirect influence of one variable upon the other by partitioning the total correlation coefficient into the components of direct and indirect effects. This has also an advantage to point out the true yield determinants for genetic improvement of crop.

\section{Materials and Methods}

The experiment was conducted at Research Farm, Zonal Agricultural Research Station, Chhindwara, Jawaharlal Nehru Krishi Vishwa Vidyalaya, (M.P.). The soil of the experimental field was sandy loam with good drainage and uniform texture with medium organic matter, low in nitrogen, low in phosphorus and rich in potash status. Chhindwara is situated on 'Satpura Hills' agro-climatic region of Madhya Pradesh at 22.0 $0^{\circ}$ North latitude, 78.0 $0^{\circ}$ East longitudes and on an altitude of 700.0 meters above the mean sea. The climate of region is typically semi arid and sub tropical having extreme winter and summer. The average annual rainfall is $1183 \mathrm{~mm}$, which is mostly received during June to October form South-west monsoon. The average maximum temperature is $43^{\circ} \mathrm{C}$ and minimum temperature $5.7^{\circ} \mathrm{C}$. The average annual relative humidity is $74 \%$.

The experimental material for this study comprised with forty five $\mathrm{F}_{1}$ 's produced by crossing fifteen lines and three testers. In the crossing programme, each of the lines was crossed to each tester in line $\mathrm{X}$ tester fashion, which resulted in $45 \quad F_{1}$ crosses. The experiment was laid out in Randomized Complete Block Design (RCBD) with 63 treatments (45 $\mathrm{F}_{1}$ 's +18 Parents) in three replications. The bottle gourd genotypes to be used as line and testers were planted in crossing blocks at two different dates of sowing at an interval of 15 days, so as to get sufficient number of flowers for bagging and pollination. The fifteen genotypes viz. JBG1, JBG2，JBG3，JBG4，JBG5，JBG6，JBG7, JBG8, JBG9, JBG10, JBG11, JBG12, JBG13, JBG14 and JBG15 were treated as female parent (lines) and genotypes such as, Pusa Naveen, Punjab Komal and Pusa Summer Prolific Long were used as male parent (tester). The crop was sown in three different seasons (1) February 2007 for crossing of line into tester to obtain $F_{1}$ hybrids (2) February 2008 to evaluate all $F_{1}$ with their parents in summer season and (3) July 2008 to evaluate all $\mathrm{F}_{1}$ with their parents in rainy season.

The observations were taken on the different yield and yield attributing characters i.e. Vine length, Primary branches/plant, Days to appearance $1^{\text {st }}$ male flower, Days to appearance $1^{\text {st }}$ female flower, Node to $1^{\text {st }}$ male flower appeared, Node to $1^{\text {st }}$ female flower appeared, Male flowers/plant, Female flowers/plant, Sex ratio, Fruit setting percentage, Days to $1^{\text {st }}$ harvest, Fruit Circumference $(\mathrm{cm})$, Fruit length $(\mathrm{cm})$, Fruit 
diameter $(\mathrm{cm}), \mathrm{Av}$. Wt. of fruit $(\mathrm{kg})$, Fruits/plant, Seeds/fruit, seed pulp ratio, Flesh thickness, Fruit yield/ plant, Fruit yield q/ ha.

\section{Results and Discussion}

Correlation coefficients are the indication of simple association between variables. In a biological system, however the relationship may exist in a very complex form. It is therefore, essential to study the relationship among variable in a comprehensive way. Path coefficient analysis is a powerful tool, which enable partitioning of the given relationships in its further components. In other words, it takes into account not only the relationship of component characters with the dependent character, but simultaneously takes care of its relationship with other component also. Thus, it helps in understanding the causal system in a better way because it enables partitioning the total correlations coefficient into direct and indirect effects of various characters.

In the present investigation path coefficient analysis was carried out for characters under study using genotypic and phenotypic correlation coefficient and taking fruit yield per plant as dependable variables, in order to see the causal factor and so as to identify the components which are responsible for producing fruit yield per plant. In general the genotypic direct as well as indirect effects were slightly higher in magnitude as compared to corresponding phenotypic direct and indirect effects. Since the values of genotypic path are more reliable in predicting the correct idea about the direct and indirect effects of the components traits has been discussed as below.

Path coefficient analysis of different traits contributing toward fruit yield per plant showed that number of fruits per plant showed highest positive direct effect followed by fruit length, circumference of fruit, fruit setting percentage, average weight of fruit, vine length, number of male flowers per plant and number of female flowers per plant. The results are in propinquity with Singh et al., (2006a) and Husna et al., (2011) for average weight of fruit and number of fruits per plant, Hawlader et al., (1999) and Singh et al., (2006a) for number of female flowers per plant, Umamaheswarappa (2004) and Yadav et al., (2010) for number of fruits per plant, Ram et al., (2005a) for weight of fruit, circumference of fruit and vine length, Ram et al., (2005) and Raja et al., (2006) for number of fruits per plant and vine length, Gayen and Hossain (2007) and Yadav et al., (2010) for fruit length and average weight of fruit. The characters number of male flower per plant, number of female flower per plant, fruit setting percentage, length of fruit, weight of fruit and number of fruits per plant, whereas, association of this trait were recorded significant and negative with sex ratio and circumference of fruit had correlation coefficient value at par with their direct effect on fruit yield per plant. This indicates true relationship with fruit yield per plant and direct selection for these traits would result in higher breeding efficiency for improving yield. Thus these traits might be reckoned as the most important component trait of fruit yield per plant in bottle gourd.

Whereas, sex ratio had the highest negative direct effect on fruit yield per plant followed by number of primary branches per plant. The findings of Raja et al., (2006) for negative sex ratio are in close harmony to the present findings. The role of these traits in the contribution towards fruit yield cannot be ignored.

\section{Positive indirect effect}

Vine length imparted highest positive indirect effect on fruit yield per plant via number of primary branches per plant followed by sex 
ratio, circumference of fruit and number of male flowers per plant. Number of primary branches per plant was reported to have highest positive indirect effect on fruit yield per plant via average weight of fruit followed by circumference of fruit, fruit setting percentage and sex ratio. Number of male flowers per plant expressed a significant positive indirect effect on fruit yield per plant through sex ratio followed by number of fruits per plant, number of female flowers per plant, number of primary branches per plant, fruit setting percentage, circumference of fruit and vine length. Number of female flowers per plant had significant positive indirect effect on fruit yield per plant via number of fruits per plant, average weight of fruit, number of male flowers per plant and number of primary branches per plant. Sex ratio manifested highest positive indirect effect on fruit yield per plant through average weight of fruit, number of female flowers per plant, number of fruits per plant, fruit length and number of primary branches per plant. Highest positive indirect effect of percentage of fruit setting on fruit yield per plant was recorded through sex ratio, number of fruits per plant, number of male flowers per plant and fruit length. The indirect positive effect for circumference of fruit was observed via average weight of fruit, vine length, sex ratio and number of male flowers per plant. Fruit length imparted a positive indirect effect through average weight of fruit, number of fruits per plant, fruit setting percentage, number of female flowers per plant and number of primary branches per plant. The indirect effect for average weight of fruit was recorded via length of fruit, number of female flowers per plant and circumference of fruit. Number of fruits per plant manifested highest positive indirect effect on fruit yield per plant through number of female flowers per plant, number of male flowers per plant, fruit setting percentage, fruit length and number of primary branches per plant.

\section{Negative indirect effect}

Negative indirect effect was visible to be highest via number of fruits per plant, number of female flowers per plant, average weight of fruit, fruit length and fruit setting percentage. However, negative indirect effect was recorded on fruit yield per plant through vine length, number of female flowers per plant, number of male flowers per plant, number of fruits per plant and fruit length. Number of male flowers per plant expressed a significant negative indirect effect on fruit yield per plant though, other traits viz., average weight of fruit and fruit length showed negative indirect effect. While, negative indirect effect of number of female flowers per plant was recorded through sex ratio, fruit setting percentage and vine length. Indirect effect of sex ratio via number of male flowers per plant, fruit setting percentage, vine length and circumference of fruit was found to be negative. But a negative indirect effect of percentage of fruit setting was seen via average weight of fruit, number of female flowers per plant, circumference of fruit, number of primary branches per plant and vine length. Other traits like fruit length, number of fruit per plant, number of primary branches per plant, fruit setting percentage and number of female flowers per plant expressed negative indirect effect for circumference of fruit. Negative indirect effect of fruit length was measured via circumference of fruit, sex ratio, vine length and number of male flowers per plant. However, negative indirect effect of average weight of fruit was found higher magnitude via fruit setting percentage, sex ratio, number of primary branches per plant, number of male flowers per plant and vine length. Number of fruits per plant exhibited indirect effects via sex ratio, circumference of fruit, vine length and average weight of fruit were found to be negative. 
Table.1 Estimation of Genotypic path coefficient among yield and its contributing characters for pooled analysis

\begin{tabular}{|c|c|c|c|c|c|c|c|c|c|c|c|}
\hline Characters & Vine length & $\begin{array}{c}\text { Primary } \\
\text { branches / } \\
\text { plant }\end{array}$ & $\begin{array}{c}\text { Male } \\
\text { flowers / } \\
\text { plant }\end{array}$ & $\begin{array}{c}\text { Female } \\
\text { flowers / } \\
\text { plant }\end{array}$ & Sex ratio & \begin{tabular}{c|}
$\begin{array}{c}\text { Fruit setting } \\
\text { percentage }\end{array}$ \\
\end{tabular} & $\begin{array}{l}\text { Circumference of } \\
\text { Fruits (cm) }\end{array}$ & $\begin{array}{l}\text { Length of } \\
\text { fruits }(\mathrm{cm})\end{array}$ & $\begin{array}{l}\text { Weight of } \\
\text { fruits } \\
\text { (Kg./fruit) }\end{array}$ & Fruits /plant & $\begin{array}{l}\text { Yield /plant } \\
\text { (Kg.) }\end{array}$ \\
\hline Vine length & 0.0444 & 0.0169 & 0.0023 & -0.0053 & 0.0074 & -0.0009 & 0.0071 & -0.0038 & -0.0051 & -0.0055 & -0.0868 \\
\hline Primary branches / plant & -0.0158 & -0.0415 & -0.0044 & -0.0049 & 0.0004 & 0.0032 & 0.0060 & -0.0011 & 0.0299 & -0.0025 & -0.0566 \\
\hline Male flowers / plant & 0.0020 & 0.0040 & 0.0385 & 0.0135 & 0.0193 & 0.0039 & 0.0031 & -0.0028 & -0.0167 & 0.0164 & 0.2657 \\
\hline Female flowers / plant & -0.0010 & 0.0010 & 0.0029 & 0.0081 & -0.0050 & -0.0031 & -0.0007 & 0.0005 & 0.0055 & 0.0055 & 0.5747 \\
\hline Sex ratio & -0.0219 & 0.0013 & -0.0661 & 0.0819 & -0.1321 & -0.0623 & -0.0197 & 0.0147 & 0.1303 & 0.0328 & -0.2837 \\
\hline Fruit setting percentage & -0.0030 & -0.0120 & 0.0156 & -0.0598 & 0.0733 & 0.1554 & -0.0214 & 0.0120 & -0.1575 & 0.0626 & 0.3429 \\
\hline Circumference of Fruits (cm) & 0.0598 & -0.0540 & 0.0303 & -0.0319 & 0.0555 & -0.0511 & 0.3722 & -0.2957 & 0.0830 & -0.0867 & -0.3232 \\
\hline Length of fruits $(\mathrm{cm})$ & -0.0547 & 0.0177 & -0.0473 & 0.0358 & -0.0715 & 0.0495 & -0.5089 & 0.6405 & 0.6068 & 0.1054 & 0.5316 \\
\hline Weight of fruits (Kg./fruit) & -0.0056 & -0.0349 & -0.0210 & 0.0331 & -0.0478 & -0.0492 & 0.0108 & 0.0459 & 0.0485 & -0.0008 & 0.7123 \\
\hline Fruits /plant & -0.0910 & 0.0449 & 0.3150 & 0.5040 & -0.1831 & 0.2975 & -0.1719 & 0.1215 & -0.0123 & 0.7383 & 0.8655 \\
\hline
\end{tabular}

$\mathrm{R}$ SQUARE $=0.9979$ RESIDUAL EFFECT $=0.0455$

Table.2 Estimation of Phenotypic path coefficient among yield and its contributing characters for pooled analysis

\begin{tabular}{|c|c|c|c|c|c|c|c|c|c|c|c|}
\hline Characters & Vine length & $\begin{array}{c}\text { Primary } \\
\text { branches / } \\
\text { plant }\end{array}$ & $\begin{array}{c}\text { Male } \\
\text { flowers / } \\
\text { plant }\end{array}$ & $\begin{array}{c}\text { Female } \\
\text { flowers / } \\
\text { plant }\end{array}$ & Sex ratio & $\begin{array}{l}\text { Fruit setting } \\
\text { percentage }\end{array}$ & \begin{tabular}{|c|} 
Circumference of \\
Fruits $(\mathrm{cm})$
\end{tabular} & $\begin{array}{l}\text { Length of } \\
\text { fruits }(\mathrm{cm})\end{array}$ & $\begin{array}{l}\text { Weight of } \\
\text { fruits } \\
\text { (Kg./fruit) }\end{array}$ & Fruits /plant & $\begin{array}{l}\text { Yield /plant } \\
\text { (Kg.) }\end{array}$ \\
\hline Vine length & 0.0440 & 0.0138 & 0.0020 & -0.0047 & 0.0058 & -0.0003 & 0.0064 & -0.0033 & 0.0003 & -0.0033 & -0.0401 \\
\hline Primary branches / plant & -0.0170 & -0.0543 & -0.0056 & -0.0051 & 0.0000 & 0.0028 & 0.0069 & -0.0014 & 0.0023 & -0.0020 & -0.0444 \\
\hline Male flowers / plant & -0.0043 & -0.0100 & -0.0969 & -0.0283 & -0.0461 & -0.0054 & -0.0076 & 0.0069 & 0.0020 & -0.0280 & 0.1919 \\
\hline Female flowers / plant & -0.0503 & 0.0445 & 0.1384 & 0.4742 & -0.3203 & -0.1604 & -0.0348 & 0.0212 & 0.0128 & 0.2164 & 0.4048 \\
\hline Sex ratio & 0.0122 & 0.0000 & 0.0439 & -0.0624 & 0.0924 & 0.0310 & 0.0118 & -0.0084 & -0.0037 & -0.0203 & -0.2252 \\
\hline Fruit setting percentage & -0.0031 & -0.0207 & 0.0225 & -0.1359 & 0.1346 & 0.4018 & -0.0346 & 0.0174 & -0.0024 & 0.2361 & 0.4752 \\
\hline Circumference of Fruits (cm) & 0.0458 & -0.0402 & 0.0246 & -0.0231 & 0.0403 & -0.0271 & 0.3149 & -0.2467 & 0.0026 & -0.0517 & -0.2159 \\
\hline Length of fruits (cm) & -0.0408 & 0.0136 & -0.0382 & 0.0240 & -0.0491 & 0.0233 & -0.4211 & 0.5375 & 0.0345 & 0.0591 & 0.3691 \\
\hline Weight of fruits (Kg/fruit) & 0.0006 & -0.0044 & -0.0021 & 0.0028 & -0.0041 & -0.0006 & 0.0008 & 0.0065 & 0.1021 & 0.0020 & 0.1574 \\
\hline Fruits /plant & -0.0272 & 0.0132 & 0.1033 & 0.1633 & -0.0787 & 0.2103 & -0.0587 & 0.0394 & 0.0070 & 0.3578 & 0.7661 \\
\hline
\end{tabular}

$\mathrm{R}$ SQUARE $=0.7647$ RESIDUAL EFFECT $=0.4850$ 
Int.J.Curr.Microbiol.App.Sci (2018) 7(12): 1256-1263

Figure.1 Genotypic path diagram

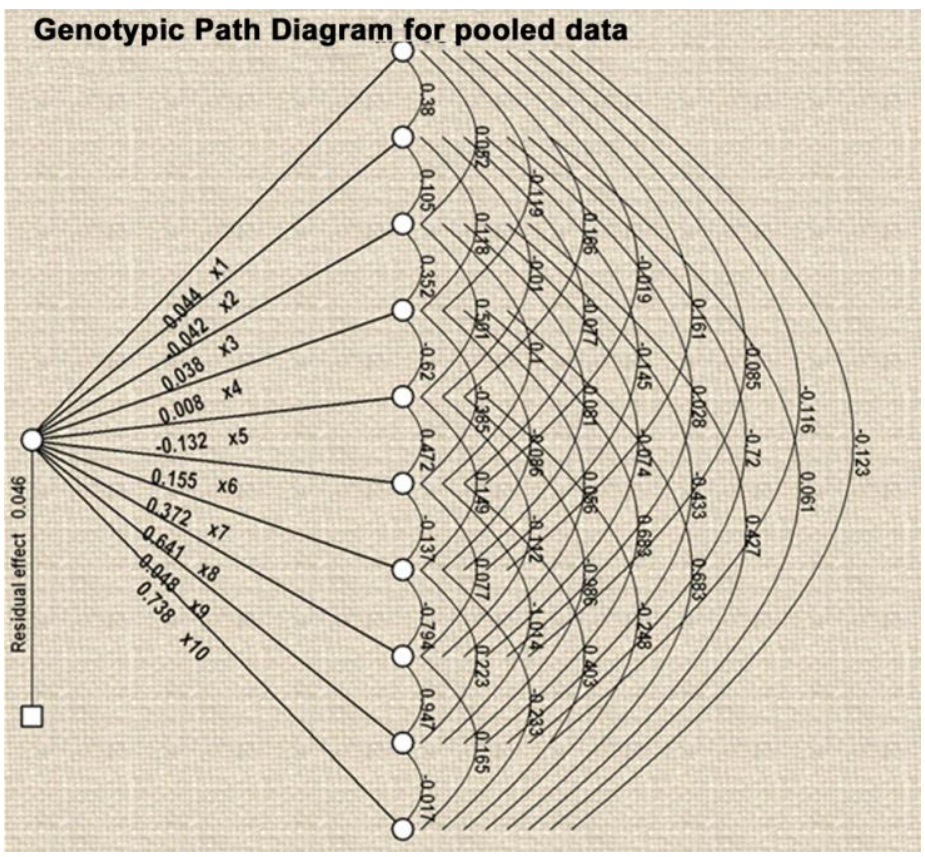

Figure.2 Phenotypic path diagram

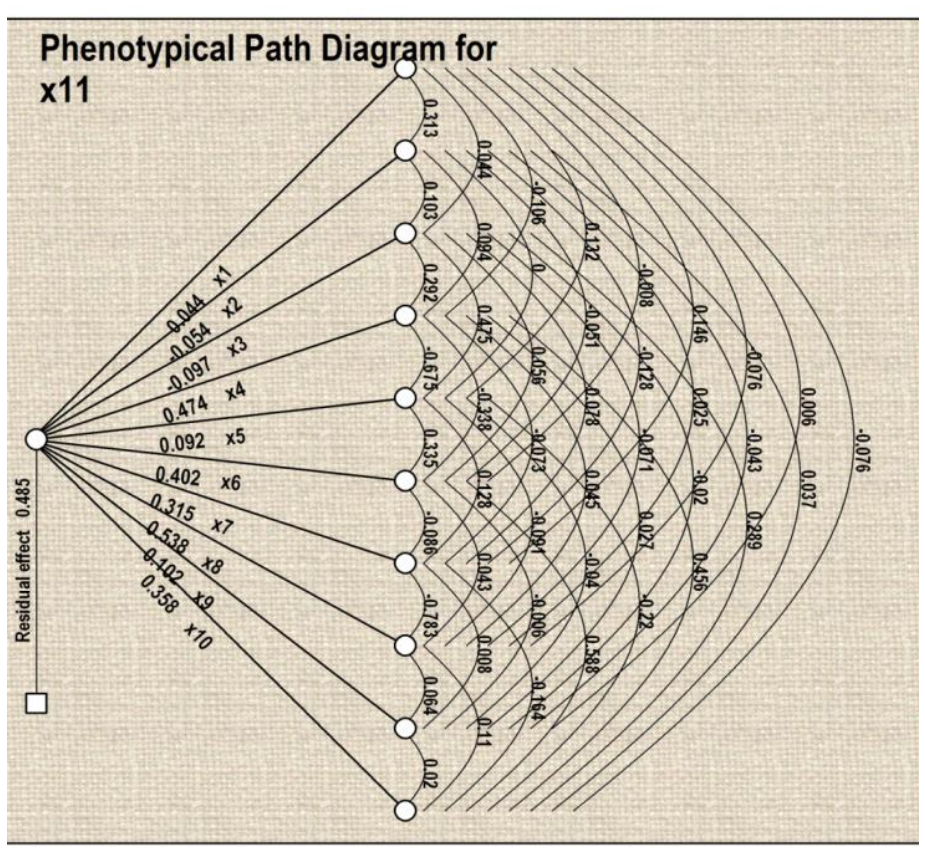


In conclusions, an overall observation of the results of path coefficient analysis of fruit yield and its components revealed that number of fruits per plant, fruit setting percentage, average weight of fruit, fruit setting percentage, average weight of fruit, vine length, number of male flowers per plant and number of female flowers per plant were the most important traits contributing towards fruit yield per plant in bottle gourd.

\section{Acknowledgements}

The authors are thankful to the Dr. Gautam Kalloo, Vice Chancellor, Jawaharlal Nehru Krishi Vishwa Vidyalaya Jabalpur for providing necessary field facility to conduct experiment and Dr. J.P. Lakhani, Associate professor, Plant Breeding \& Genetics, JNKVV for supporting data analysis work.

\section{References}

Badade, D. S., Warade, S. D., Gaikwad, S. K. 2001. Genetic divergence in bottle gourd [Lageneria sicereria (Mol.) standl). J Maharastra Agric Univ 26 (2): 137-139.

Gayen, Nikhil and Hossain, Manjur 2007. Correlation and path analysis in bottle gourd (Lagenaria siceraria (Mol) Standl). Environment and Ecology 25 (1): 193-195.

Hawlader, M. S. H., Haque, M. M., Islam, M. S. 1999. Variability correlation and path analysis in bottle gourd [Lageneria sicereria (Mol) stand]. Bangladesh $J$ Scientisic and industrial Research 34(1): 50-54.

Husna, A., Mahmud. F., Islam, M. R., Mahmud. M. A. A., Ratna, M. 2011. Genetic Variability, Correlation and Path Co-Efficient Analysis in Bottle Gourd (Lagenaria siceraria L). Advances in Biological Research 5 (6): 323-327.
Miller, D. A., Williams, J. C., Robinson, H. F., Comstock, K. B. 1958. Estimates of genotypic and environmental variances and covariances in upland cotton and their implication in selection. Agron $J$ 50: 126-131.

Parvathi. L. and Reddy, E. N. 2006. Correlation studies in bottle gourd [Lageneria sicereria (Mol) stand]. $J$ of Res ANGRAU 31(1): 98 -100.

Raja, S., Bagle, B. G., Dhandar, D. G. 2006. Identification of yield attributes in bottle gourd for rainfed condition. Veg Sci 33 (1): 106-108.

Ram, D., Singh. R. S. Pandey, Sudhakar, Rai, Mathura 2005. Studies of polygenic traits in off-season bottle gourd (Lagenaria siceraria (Mol) Standl). Vegetable-Science 32 (2): 189-191.

Ram, D., Rai, M., Rai, N., Yadav, D. S., Sudhakar, Pandey, Verma, A. Lal, H., Singh, N. Singh, Sudhir 2007. Characterization and evaluation of winter fruited bottle gourd [Lagenaria siceraria (Mol) Standl]. Acta Horticulturae (752): 231-237.

Sarvesh, Kumar, Singh. S. P. 1998. Correlation and path coefficient analysis for certain metric traits in bottle gourd [Lageneria sicereria (Mol.) stand]. Veg Sci 25 (1): 40 -42.

Sengupta, S. K., Singh, K. P., Nair, Beena 2011. Genetic studies in bottle gourd. Abstract of National Symposium on Vegetable Biodiversity, held at J.N.K.V.V. Jabalpur during April 4-5, 2011. pp 26.

Singh, K. P., Choudhary, D. N., Mandal, G. and Saha, B. C. 2006a. Correlation and path coefficient analysis in bottle gourd (Lagenaria siceraria (Molina) Standl). Journal of Interacademicia 10(3): 309313.

Singh, P. P. 1998. Genetic analysis of yield and yield attributes in bottle gourd (Lagenaria siceraria (Mol) Standl.). Ph. 
D. Thesis, Department of Vegetable Science, N.D. Univ. Agri. Tech., Kumarganj, Faizabad. (U.P.).

Umamaheswarappa, P., Krishnappa, K. S., Murthy, P. V., Nagarajappa, Adivappar, Muthu, M. P. 2004. Correlation and path coefficient analysis studies in bottle gourd (Lagenaria siceraria $(\mathrm{Mol})$ Standl) cv Arka Bahar. Environment and Ecology 22 (Spl-4): 636-640. Yadav, Yogesh, Chandra, Kumar, Sanjay, Kumar, Adesh, Singh, Raghvendra, Singh, Rekha 2010. Path coefficient studies and character association in bottle gourd (Lagenaria siceraria (Molina) standl). Annals of Horticulture 3 (1): 84-88.

\section{How to cite this article:}

Raut, R.L., S.P. Mishra and Sharad Bisen. 2018. Path Analysis and Correlation Study of Yield and Its Measure Contributing Traits in Bottle Gourd (Lagenaria siceraria (Mol.) Standl). Int.J.Curr.Microbiol.App.Sci. 7(12): 1256-1263. doi: https://doi.org/10.20546/ijcmas.2018.712.155 